\title{
Exploring the Motive and Effect between Altruistic and Strategic Corporate Giving: An Experimental Design Study
}

\author{
Quey-Jen Yeh $^{1}$ \\ ${ }^{1}$ Department of Business Administration, National Cheng-Kung University, Taiwan \\ Correspondence: Quey-JenYeh, Department of Business Administration, National Cheng-Kung University, Taiwan.
}

Received: November 15, 2017

doi:10.5430/bmr.v6n4p76

\begin{abstract}
Corporate giving has evolved into more than altruistic actions to include strategic considerations. Drawing on attribution and signaling theory, this study designs two social giving scenarios with one designed to be more sales related, tending to take the advantage of social cause than the other. Our goal is to examine whether the public recognize the difference between the two and how they interpret such a signal in relation to the firm's standing in reputation, consumer attitude and purchase intention. The results support largely the conceptual framework in that corporate giving strategy could be more beneficial when it is designed to be more altruistic.
\end{abstract}

Keywords: Corporate philanthropy, Altruism, Strategic giving, Motive attribution, Experimental design

\section{Introduction}

Studies in the social level of corporate social responsibility (CSR), or philanthropy, concern the acts of a company that promote the welfare of others via charitable donations of funds or talents to existing non-profit organizations. The talents can be in the form of use of the company's facilities or volunteer time offered by the company's employees. Scholarly studies have evidenced win-win situation in the programs: The nonprofit cause receives the needed supports, and the company earns sales and visibility, because through such partnership, the public portray the two parties as social responsible mindedness, even patriotism image (e.g., Varadarajan \& Menon, 1988; Webb \& Mohr, 1998).

Regardless the successes, academics have long debated the merits of corporate giving and its altruistic or strategic signal. The conclusions appear diverged. Traditionally, economists assert that the sole objective of a corporation is shareholders' value, such that corporate giving without their permission is the same as firm managers stealing from shareholders (Firedman, 1970). Therefore, there appears to be no altruistic reasons for a corporation to give away shareholders' money purely for philanthropy. However, Elfenbein et al. (2012) found that fewer customers complain charity-intensive sellers, particularly when they have limited means of assuring quality from sellers who are relatively new, so that consumers respond positively to products tied to charity. In contrast, Based on macroeconomic variables to measure public charitable need and test for altruism, Gan (2006) proposes that company's vulnerability to public scrutiny drives its giving behavior, and that corporate giving is both strategic and altruistic. Whereas, Peloza et al. (2009) evidence that volunteer opportunities that fulfill egoistic and organizational citizenship motivates are effective, but those fulfilling altruistic motive is not significant, in increasing the effectiveness of corporate philanthropy.

Seeking to identify the legitimate role of corporate philanthropy, Porter and Kramer (2002) point out that most corporations believe that they are doing strategic charities because of reputational improvement and consumers' recognition of their brands and products, but in fact they are not. In the same vein, Ricks and Williams (2005) indicate that there is purpose for corporate giving beyond altruism, and meeting the strategic goal is an important one. Henderson and Malani (2009) also assume the potential of altruistic market when there is comparative strategic advantage over simply the government or nonprofit causes. Cantrell et al. (2015) further argue that if firms can well manage key internal and external stakeholder relationships, CSR-giving can be developed as a more strategically driven process with benefits leading to increased organizational productivity. It appears that corporate giving has evolved into more than an altruistic action to one which is embedded in the strategic frame of management.

Previous studies apparently tend to look at corporate giving as a strategic avenue. This study therefore questions: For a corporate giving, will people detect such strategic essence? Or will they simply view it as a signal of altruism? 
Either way, how people connect such a giving signal to the firm's social image? We aims to bridge the gap by proposing that this avenue could be even more beneficial when it is designed to be more altruistic.

To answer the question, this study draws on CSR- philanthropy attribution complement with signaling theory (e.g., Spence, 2002; Mavlanova, et al., 2012; Connelly, et al., 2011) to conduct two experimental studies. Remote elementary school and stray animal shelter were chosen as the causes. Two fictitious companies represent respectively the altruistic- and the strategic- type of giving in each study were designed. The purpose is to distinguish the signaling effects of altruistic and strategic attributions between the two, and how such a signal is related to the firm's standing, including firm reputation, and consumer attitude and purchase intention.

\section{Literature Review}

\subsection{Corporate Giving: Altruism or Strategic Purpose?}

The definition of CSR philanthropy, although is altruistic, is in certain degree contrary to the traditional definition of business for profit making. Philanthropy in business is in many ways a compromise of two seemingly contradictory perspectives: Corporations may take altruistic actions, but they do so under profit constraints (e.g., Gas, 2006). Regardless, businesses doing non-business social works, known as strategic giving, is demonstrated beneficial to a firm's strategic position and ultimately its outcome (e.g., Saiia, Carroll, \& Buchholtz, 2003). Mostly, companies believe philanthropy or corporate giving is strategy-oriented, because the causes can help them with strategic assets such as reputational capital, employee commitment, trust, and eventually consumers' recognition of their brands and products (Porter \& Kramer, 2002).

Perhaps, the controversies is due to excess manipulation of the causes. According to Berman et al. (2015), corporate may brag about, or signal, their good deeds. The effect of cause-related products is alike bragging by signaling a mingled motive for doing good deeds. Although it transfers information about the firm's good deeds and can lead to a perception of generosity, bragging also entails a purpose for credit, a sales-related motive that hurts the initiative. Particularly, bragging will generate positive effects when the giving behavior is unknown because it informs public the deeds of generosity, while it does not help, and may damage, when the behavior is already known since it may turn to a signal of sales-related purpose. Berman et al. (2015) thus conclude that bragging giving not only undermines the information that braggart is trying to convey for generosity, but also can hurt the strategic consideration inherited in altruistic conducts.

\subsection{Attribution and Signaling}

Attribution, which means the act of searching for the cause or reason, occurs when an individual perceives an outcome as unexpected, negative, or dissatisfying (Weiner, 1985). Because of this post-initial-cause-search character, attribution is often viewed as an explanatory factor of stakeholders' cognitive reactions and intervenes in decisionmaking after a product-related outcome and prior to the next choice (Weiner, 2000). Extent research has investigated the scope of motive consumers attribute to CSR efforts, because in an environment of limited trust, public's doubt about concealed motives gives much inspiration to why questions, leading to more sophisticated perceptions and attributions (Ellen et al., 2006). These contemplations indicate that CSR halo on people behavior may extend beyond product and brand evaluations into non-routine types of judgments, and other sentimental attitudes (e.g, Castaldo et al., 2009; Du \& Chandran, 2009; Pivato, et al., 2008).

Signaling theory accentuates that some signals are reliable and others are not, and that the costs of falsifying a signal surpass the benefits (Spence, 2002; Mavlanova, et al., 2012; Connelly, et al., 2011). Social cause, acting as a signal, makes the public more favorable for the brands that are tied to the cause as compared to those that are not, stimulating social image as a marketing mechanism to impact on outcome in terms of trust and goodwill (e.g., Pivato, et al., 2008). However, although non-profit giving is altruistic in definition, it often accompanied with the conflicting idea that companies taking social actions entail more or less to economic imagination (Gan, 2006). Consequently, attributions concerning genuinely helping the society or strategic goals of getting and keeping customers may be widely accepted as a signal of social actor, but one which is perceived as taking advantage of the society may generate negative, egoistic linkage and are less likely to be accepted (Ellen et al., 2006).

Overall, this research seeks to enhance our understanding of consumers' perception or attribution about the motives behind the giving and how it relates to personal attitude and firm reputation. The focus is on that public will sense a higher level of altruism and so will be more positive about the firm when it is perceived implementing altruistic, no-sales-related giving, because such giving passes a signal of helping the society without anticipating payback. In contrast, the public will feel a higher level of egoistic, sales-related giving, and so will be less positive about the firm when it is perceived implementing performance or strategic giving, because such giving passes a signal of taking 
advantage of non-profit or cause as a way to increase sales, profit, or reputational capital. Two studies using experimental design were conducted separately to examine the purposes. Their propositions and research procedures, including the findings, are describes below.

\section{Study 1}

Study 1 aims to examine how people attribute the motive of a corporate giving. Ellen et al. (2006) suggest that there are three driven dimensions in attribution theory in general: values-driven, stakeholders-driven, and strategy-driven, to determine the extent to which consumers are likely to attribute a company's motive in taking social plans. The values-driven is initiated by obligated morality for helping the society; the stakeholders-driven is because of the requests of stakeholders including investors, customers, employees, and social communities; the strategy-driven is because of marketing strategy or government regulation.

Accordingly, two types of corporate giving are designed: 'Sales-related' presents a marketing-oriented donation in relation to company's sales, and 'no-sales-related' presents talents or volunteer as the CSR-giving plan and shows no strategic purposes. The design tends to examine if consumers recognize between the two giving scenarios in terms of the three driven motives, and if this relationship impacts further on their attitude toward the firm. Thus, assuming that no-sales-related giving makes consumers feel more socially responsible and more value-driven than sales-related, Study 1 hypothesizes,

H1: Compared to sales-related corporate giving, no-sales-related type of giving will give consumers a higher level of values-driven, and a lower level of stakeholder- or strategy- driven attribution.

H2: Value-driven attribution is related more positively to consumer attitude toward the firm than both stakeholders-driven and strategy-driven attributions.

A questionnaire, each with a comparison between the two scenarios and the responses, was developed. As described below, there are three measuring instruments in the questionnaire of Study 1: Two corporative giving scenarios offered by two fictitious firms, followed by two response measures in consumer attributions and attitude toward the two firms using a two-sided seven Likert type scale. Respondents were asked to rate the responses after reading the experimental stimuli. Therefore, in terms of the framework, consumers' attribution of a firm's motive in the giving represent a mediation between the giving and consumer attitude toward it.

\subsection{The Scenarios}

People exhibit patterns of decision making in relation to information framing in that different frames may change people's mindset for decision choices (Levin, Schneider and Gaeth, 1998). Within the framing, attitude or perception acts as the key factor in explaining people's responses to a firm's doings. We starts with two posters introducing the social cause and the giving actions of two fictitious paper/book manufacturing firms $\mathrm{A}$ and $\mathrm{B}$, where the giving of Company A is designed as no-sales-related and Company B sales-related. Their scenarios are as below:

'Company A values social works and responsibilities. Each year, Company A donates books and a thousand cash (30 Taiwan\$ $=1$ US\$) to elementary schools in remote area, and constantly help them to fix damaged classroom and equipment.

'Company B announces a "Buy more, Donate more activity". For a purchase over 30 Taiwan\$, Company B promises to donate $5 \%$ of the purchase amount to elementary schools in remote area to fund them buy books and repair damaged classroom and equipment.

A separate question followed to ask respondents which scenario asked them to purchase product to confirm if they have recognized the difference between the two scenarios, donating books and cash or buy to get donation, for manipulation check.

\subsection{Measurements}

CSR Attribution. This measure pertains to the giving scheme perceived by consumers in making causal explanations about the narrative after reading. These attributions, consisted of values-driven, stakeholders-driven and strategic-driven, determine the extent to which consumers are likely to positively react to a company's social initiatives (Groza, Pronschinske \& Walker, 2011). As shown in Table 1, it consists of 9 items adopted and modified from existing attribution scales (Ellen, et al., 2006; Groza, Pronschinske \& Walker, 2011).

Consumer Attitude toward the Firm. This measure pertains to the attitude of consumers after reading the narrative about the firm. Bhattacharya and Sen $(2004 ; 2001)$ indicate that consumers may react to a firm's signal or action in such attitude as like/dislike or favorable/unfavorable. As shown in Table 1 below, it consists of 3 items modified 
from Nan and Heo (2007).

The choice option in the two measures is on a seven-point continuum, centered at null and anchored by the name 'Company A' and 'Company B' on the two sides. Respondents were asked to rate closer to the left if they felt Company A fit more to the meaning of the measure, otherwise, they rated closer to the right for Company B. Factor analysis retracted three driven dimensions attributed to the firms-values-driven, stakeholder-driven, and strategic-driven - with acceptable Cronbach reliabilities $(0.824,0.921,0.730$ respectively). Factor analysis retracted one attitude dimension with acceptable Cronbach reliabilities 0.934 .

Table 1. Measurements in Study 1

\begin{tabular}{l}
\hline A. Consumer Attributions between the two firms: \\
1. Which firm is more morally obligated to help society? \\
2. Which firm is more genuine in trying to give something back to society? \\
3. Which firm has a higher long-term interest in society? \\
4. Which firm is doing CSR more because customers expect it? \\
5. Which firm is doing CSR more because they feel it is social trend? \\
6. Which firm is doing CSR more because stockholders ask for it? \\
7. Which firm is more beneficial from the initiative? \\
8. Which firm will get more customers by doing so? \\
9. Which firm will keep more customers? \\
\hline B. Consumer Attitude between the two firms \\
1. Which firm is more positive to you? \\
2. Which firm do you like more? \\
3. Which firm do you feel more favorable?
\end{tabular}

\subsection{Sampling}

In order to ensure the design validity, a manipulation check that asked which company asked to buy applies to eliminate respondents who did not pay attention fully to the story. A total of 215 questionnaires were distributed and 194 valid questionnaires returned. After the survey, participants were told that the scenario was fictitious and that by random drawing, ten percent of them would get a convenient store coupon for appreciating their participation in the test.

Of the total sample profile, there were $49 \%$ male and $51 \%$ female, and about $63 \%$ were students, $37 \%$ were working persons. The age distribution was 31\%, 54\%, 12.0\%, and 3\% for those under 20, 21-30, 31-40, and over 41 respectively. Most respondents had a college degree (88\%). Participants in this research thus were mostly undergraduate and graduate students. Although such a sample is not the most ideal, it provides a homogeneous sample in enhancing the internal validity of an exploratory experimental research (Stockmyer, 1996).

\subsection{Findings}

Table 2 shows the rating of respondents in their perceived attributions of the two scenarios. As shown, firm A, the one designed for no-sales-related giving scenario, has an average values-driven value (2.25) significantly higher than the overall average (2.14), and the one of firm B (1.35). On the contrary, firm B, the one of sales-related giving, has both stakeholder-driven (2.25) and strategic-driven (2.22) values significantly higher than the averages (2.05 and $2.01)$, and those of firm $\mathrm{A}$ (1.06 and 0.93).

Further, these differences not just occurred significantly in the rating, but also in the number of respondents who reported the rating: Approximately 88\% (171) reported firm A as values-driven, and approximately $83 \%$ (161 and 162) reported firm $B$ as stakeholder- and strategic driven. If we view the effect of the three driven along the seven-point continuum from firm A to firm B as shown in Figure 1, the significant gaps between the two firms in the three driven scales show that consumers are able to distinct between the two firms in terms of the attribution theory. 
Table 2. The average driven attribution between the two scenario firms

\begin{tabular}{lc|cc|l}
\hline Attribution & $\begin{array}{c}\text { Overall } \\
\text { average }\end{array}$ & $\begin{array}{c}\text { Firm A } \\
\text { (No-sales-related) }\end{array}$ & $\begin{array}{c}\text { Firm B } \\
\text { (Sales-related) }\end{array}$ & F-value \\
\hline Values-driven & 2.14 & 2.25 & 1.35 & $376.36^{* * *}$ \\
\hline Stakeholder-driven & 2.05 & 1.06 & 2.25 & $458.92^{* * *}$ \\
\hline Strategic-driven & 2.01 & 0.93 & 2.22 & $360.79^{* * *}$ \\
\hline$* * \mathrm{p}<001 * * \mathrm{p}<01, * \mathrm{p}<.05$ &
\end{tabular}

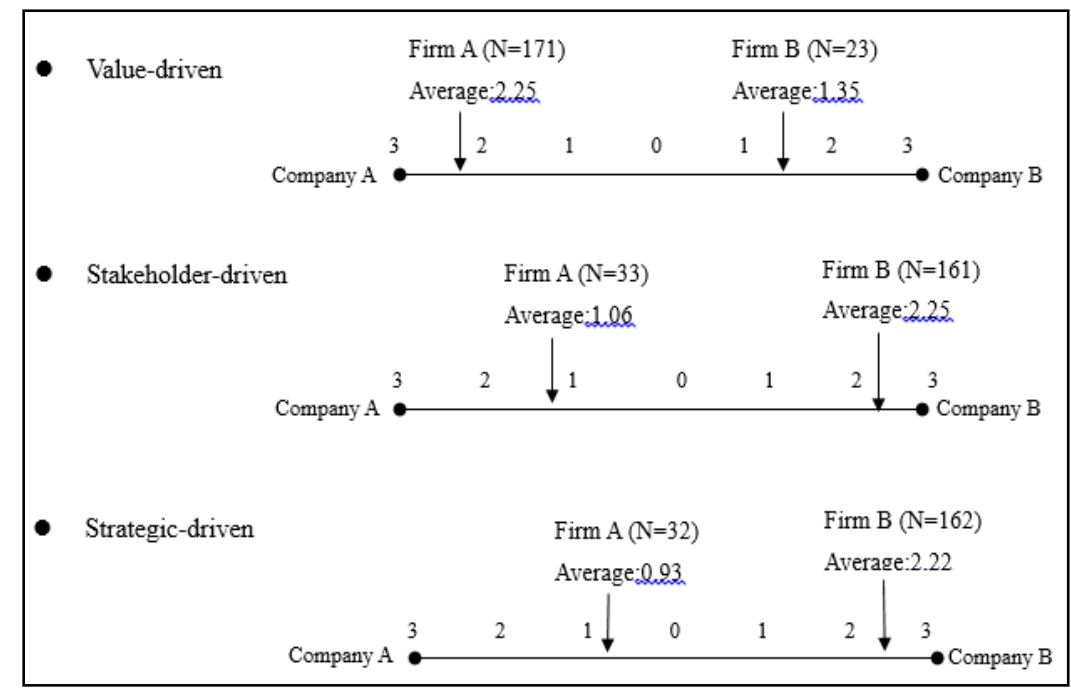

Figure 1. Comparing motives along continuum between the two scenario firms

Equation (1) shows the results of regression of the three attributions on consumer attitude toward the firm, where means the regression coefficient is significant at $\mathrm{p}$-value $=0.001$ statistical level:

Consumer attitude toward the firm $=$

$0.301^{* * *} \times$ Values-driven $-0.345^{* * *} \times$ Stakeholder-driven $-0.319^{* * *} \times$ Strategic-driven $-0.023 \times$ Gender +

$0.098 \times$ Education $-0.012 \times$ Age $+0.049 \times$ CSR concerns

As the regression in model (1) displays, the impact of value-driven is significantly positive on the attitude, while the other two, stakeholder- and strategic -driven, are significantly negative. The personal data, including gender, education, age, and CSR concerns, are all insignificant. In addition, since the three driven were compared based on relative, rather than absolute way, the positive and negative signs in Equation (1) should be explained relatively. Namely, the coefficients of different signs represent a gap instead of an absolute superior or inferior extent. Together, Equation (1) suggests that companies need to oversee their CSR social plans on the values-driven aspects and reduce the stakeholder- and strategic- driven aspects to the public.

\section{Study 2}

Study 2 aims to verify the relationship between corporate giving and CSR reputation and if this relationship impacts further on consumer purchase intention. The traditional economic theory asserts that increasing shareholder's value is the sole objective of a corporation, such that corporate giving is practically the same as managers of the firm stealing from shareholders (Firedman, 1970). Therefore, there appears no altruistic reasons for a corporation to give away shareholders' money purely for philanthropy (e.g., Gan, 2006). Under this premise, it thus is natural for consumers to suspect if a firm's motive in CSR-giving is simply altruistic. It is hence easy for consumers to turn a well-intentioned cause into bad ideas if the cause is detected for concealing self-interest or clumsy purpose. The negativity theory due to unreliable signaling may pose risks to a firm's goodwill and reputation (e.g., Connelly et al, 2011; Pivato, et al., 2008).

Therefore, Study 2 assumes that when a firm implements no-sales-related giving, consumers would perceive that it is more committed to CSRs and rate it higher reputational than one which implements sales-related giving. In addition, firm reputation as a mediator would impact on their purchase intention toward the firm's products. 
H3: Consumers perceive a corporation implementing no-sales-related giving more committed to CSRs, compared to one that implements sales-related giving.

H4: CSR commitment is related positively to firm reputation.

H5: Firm reputation as a mediator impacts positively on consumer purchase intention.

\subsection{The Scenarios}

In Study 2, we starts with two posters introducing the stray animal protection activities of two fictitious pet food corporations, because Mahatma Gandhi, the Father of India, once cited: "The moral progress of a nation and its greatness should be judged by the way it treats its animals." In which, Company A is framed as no-sales-related giving and Company B is as sales-related. The scenarios are as below:

"Company A wants their employees to volunteer two hours per week at Stray Animal Shelter, including feeding the animals, clearing up the environment, and adoption assistance."

"Company B announces that if you buy a bag of 15 kilogram pet food, they will donate 1 kilogram to the Stray Animal Shelter under your name. The more you buy, the more you donate."

\subsection{Manipulation check}

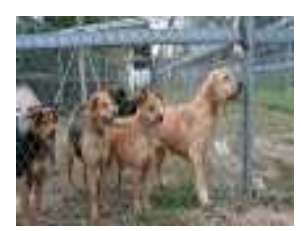

Two scales follow to ask respondents about their perception of the two companies is altruistic or egoistic, with name 'Company A' on the left of the first scale, and 'Company B' on the second, so that the interests of the two firms can be evaluated independently. The choice option is on a seven-point continuum, centered at null and anchored by 'others-interested and self-interested' on the two sides. Respondents were asked to rate closer to the left if they felt the firm fits more others-interested, otherwise, they rated closer to the right for self-interested. The purpose is to confirm the validity of the perceived altruistic or strategic extent of the two corporate giving scenarios designed.

\subsection{Measurements}

CSR Commitment. This measure pertains to the devotion of corporation in CSR doings. As shown in Table 2, it consists of seven items modified from the CSR attribution scales of Ellen et al. (2006) and Groza et al. (2011). In which, we combine stakeholders- and strategy-driven to one construct, because they both are less value-motivated and more strategic, such as doing CSRs due to stakeholder requests or social trend.

Firm Reputation. This measure pertains to consumers' perception of a firm's reputation related to its CSR initiatives. The reputation of a firm reflexes how society envisages its managerial practices and behavior, acting as a marketing mechanism to impact on its performance in terms of trust and goodwill (e.g., Pivato, et al., 2008). As shown in Table 2, it consists of three items modified from Newburry's reputation scale (2010).

Purchase Intention. This measure pertains to consumers' intention in purchasing a firm's product based on its signal and selling situations. Dodds et al. (1991) define it as the likelihood that consumers accept a deal or consider to buy, and thus should comprise three aspects: If possible to buy now, if possible to buy in the future, and if possible to recommend to others. As shown in Table 2, this measure consists of six items modified from Dodds et al. (1991).

The choice option in these measures is on a seven-point continuum, centered at null and anchored by the name 'Company A' and 'Company B' on the two sides. Respondents were asked to rate closer to the left if they felt Company A fits more to the meaning of the statement, otherwise, they rated closer to the right for Company B. Factor analysis retracted two factors in the CSR commitment measure, with Cronbach reliabilities 0.829 and 0.438 respectively. Because of the low reliability of the second factor, these items were removed and only the first factor continued the subsequent analysis. Factor analyses retracted one dimension with acceptable Cronbach reliability 0.898 , and 0.961 in the firm reputation and purchase intention measures respectively. 
Table 3. Measurements in Study 2

\begin{tabular}{l} 
A. CSR commitment between the Two Firms: \\
\hline 1. Which firm is more socially responsible? \\
2. Which firm appears to put more efforts for social benefits? \\
3. Which firm is more genuine in giving back to society? \\
4. Which firm appears to have a higher long-term care for society? \\
5. Which firm is more morally obligated to help society? \\
6. Which firm is more beneficial from CSR initiatives? (Removed) \\
7. Which firm is doing CSR more simply because it is social trend? (Removed) \\
\hline B. Firm Reputation between the Two Firms: \\
\hline 1. Which frim do you like better? \\
2. Which firm do you respect and honor more? \\
3. Which firm do you think will have higher reputation at large? \\
\hline C. Consumer Purchase Intention between the Two Firms: \\
\hline 1. Which firm's product is a better choice? \\
2. Which firm's product would you be more willing to buy? \\
3. Which firm's product would you be more possible to buy? \\
4. Which firm's product would you be more willing to recommend friends to buy? \\
\hline Wing $\quad$ Which firm's product would you be more interested to buy in the future?
\end{tabular}

\subsection{Sampling}

In attempt to investigate a sample of broader demographic characteristics, different questionnaire distribution channels such as direct distribution in shopping malls and supermarkets, online surveys via Facebook and PTT were all used simultaneously to approach the general public.

A total of 302 valid questionnaires were returned. Of the total sample profile, there were $37.1 \%$ male and $61.9 \%$ female, and about $40 \%$ were students, $60 \%$ were working persons. The age distribution was $17.9 \%, 35.1 \%, 38.4 \%$, and $8.6 \%$ for those under 20, 21-30, 31-40, and over 41 respectively. Most respondents have a college degree $(70.2 \%)$, follow by those with a master degree $(25.2 \%)$.

\subsection{Findings}

Figure 2 shows the rating of respondents in their perceptions of altruism or egoism extent of the two scenario companies for manipulation check. In which, Company A, namely the one of no-sales-related, was rated 2.21 for altruism; and Company B, the one of sales-related, was rated 2.07 for egoism on average. Apparently, the two companies are on the two different extremes of the scale with a gap of 4.28 significantly at a seven point scale. Thus, these data reveal that the respondents perceive the non-sales giving scenario, that is, company A, is more altruistic, and the sales giving scenario Company B is more egoistic, or self-centered.

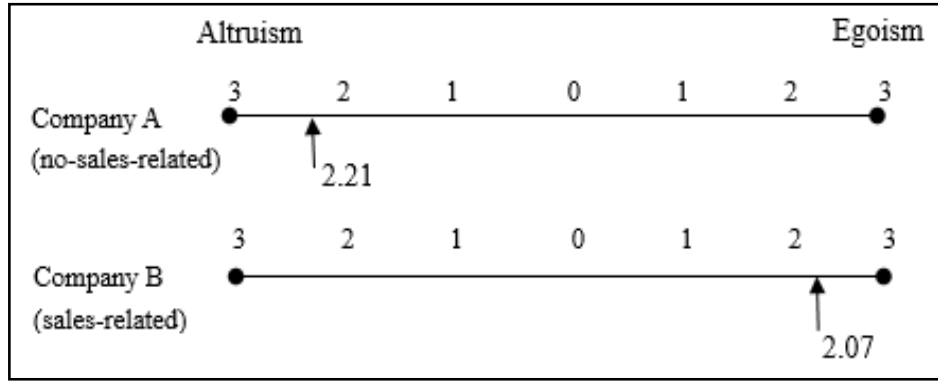

Figure 2. Perceived altruism or egoism between the two scenario firms 
Figure 3 shows the scores of the two firms on CSR commitment, perceived firm reputation, and purchase intention respectively. The gaps between the two average scores in the three variables are all significantly larger than 4.5 , and all in the similar left and right extremes centered at neutral 0.

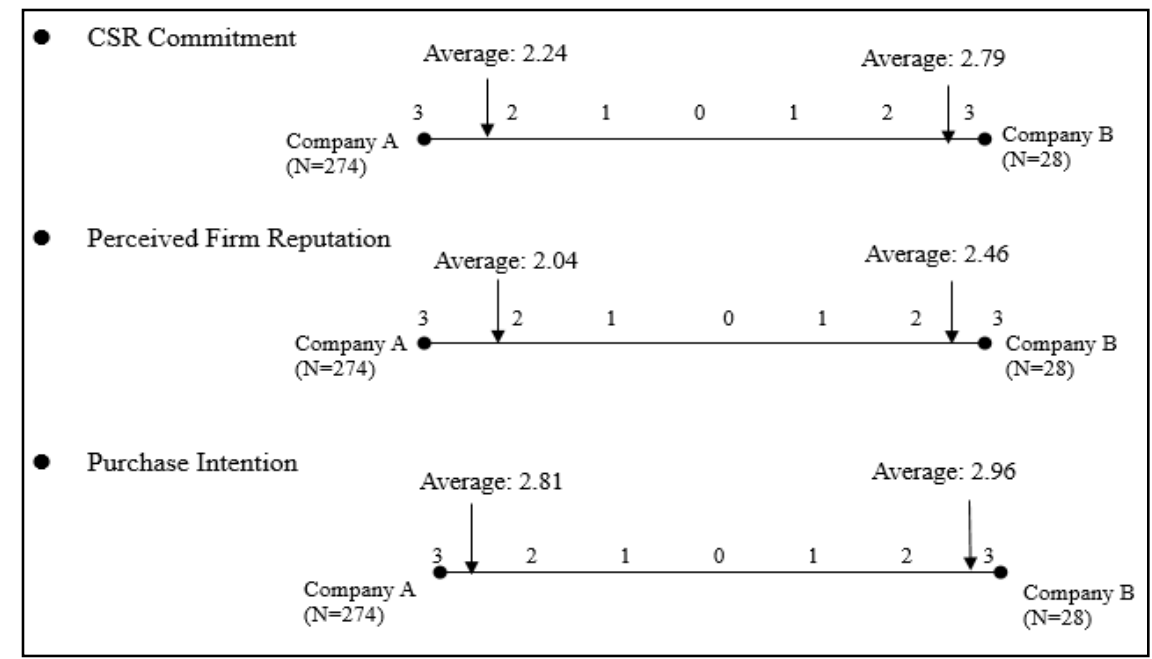

Figure 3. Perceived CSR commitment, firm reputation, and purchase intention between the two scenario firms

Table 3 shows the mediating regression of firm reputation on the relationship between CSR commitment and purchase intention. Model 1 and Model 2 display respectively that CSR commitment impacts significantly on firm reputation (coefficient $=0.695$ ) and purchase intention (coefficient=0.629). However, Model 3, which inserts firm reputation as the second independent variable, reveals its significant impact (coefficient $=0.622$ ), and meanwhile largely reduces the impact of CSR commitment (coefficient=0.197). Namely, the result shows that when competing with firm reputation, the impact of CSR commitment becomes much weaker, suggesting the mediating role of firm reputation in the model, regardless the scenario is sales-related or not. Yet, if re-checking the data in Figure 3, where there were ten times of respondents (274) agreeing that Company A was CSR committed and reputed to prompt them to buy than were Company B (28), the story appears to suggest that Company A --no-sales-related giving scenario-can earn much more population than the one earned by sales-related.

Table 3. Mediating regression of firm reputation on relationship between CSR commitment and purchase intention

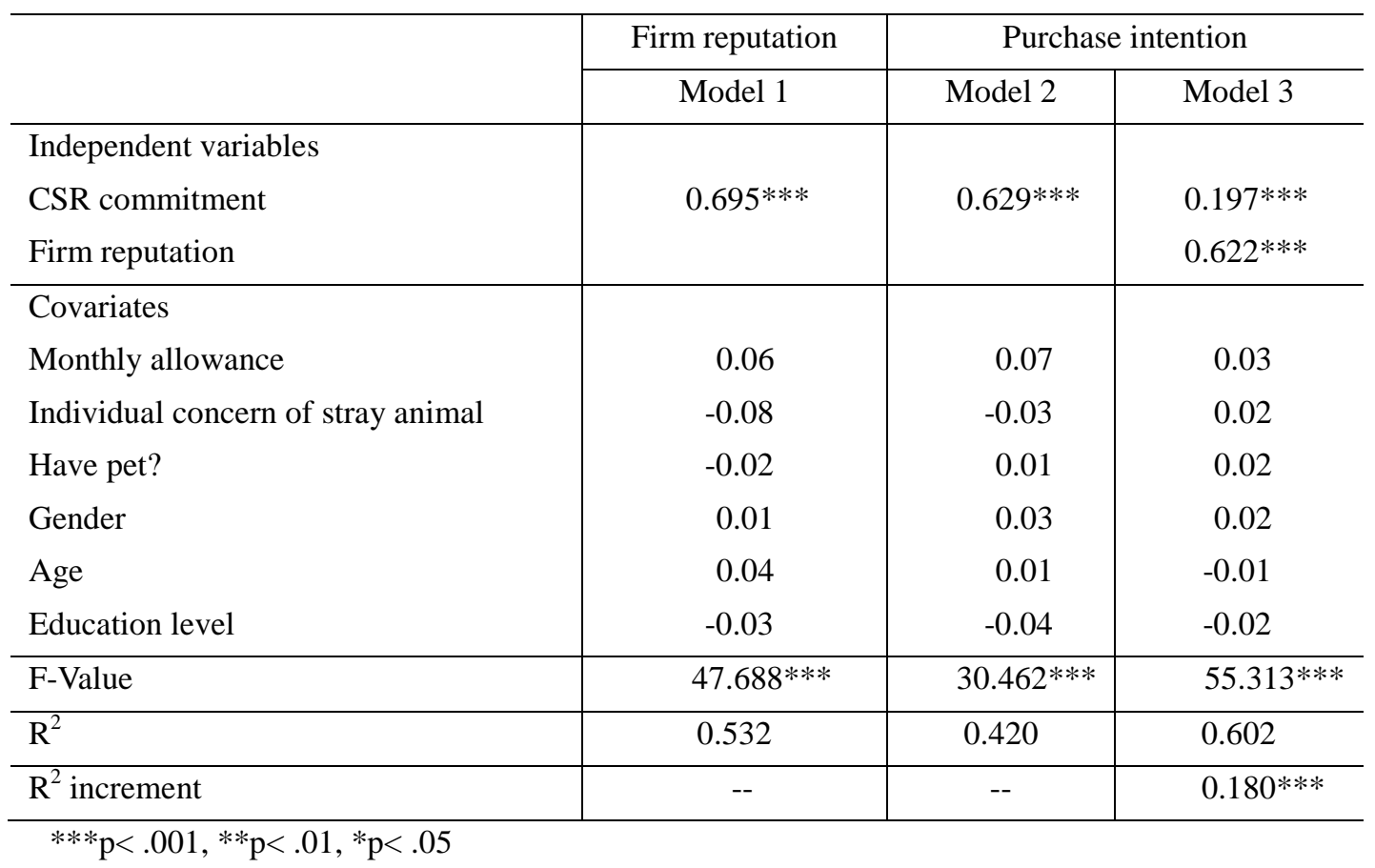




\section{Conclusions}

\subsection{Findings}

To reduce risk and avoid being cheated, buyers look for extrinsic cues of unobservable product quality. In response, firms issue signals, including advertising, brand, warranties, and CSR initiatives. Among which, CSR appears increasingly prevailing, because consumers who lack the ability to determine a product's value before purchasing are more likely to associate CSR-giving as a positive sign that connects to the firm's honesty and reliability.

Public's attribution of corporative motive is key to the success of corporate giving. Drawn on attribution and singling theories, this article shows that when a firm implements no-sales-related giving signal, the public would believe that it truly wants to help the society and so will be more positive about the firm; while when a firm implements sales-related giving signal, the public will think that it conducts the activities because of sales pressure or attending for reputational capital and so are less positive. The reason behind may be because that consumers believe that a firm of others-serving endeavor is more willing to help the society without an expectation of self-benefit; in turn, they credit it higher firm reputation with greater purchase intention. On the contrary, if it gives consumers a sales-related perception, consumers would think that the firm takes the advantage of cause or non-profit, and thus rate a weaker positive attitude, including less good reputation and purchase intention rating, toward the firm.

Mainly, consumers prefer altruistic, or no-sales-related social behavior more than performance- centered scheme in corporate giving. This conclusion directly leads to two implications. Firstly, a firm should implement altruistic-giving effort, such as adoption of volunteer programs, because in this way consumers are more likely to believe that the firm feels obligated to help the society without expecting feedback, and in turn generate a good image of it. Secondly, consumers often interpret a firm's social behavior with a subjective, philanthropic aspects. Relatively, because strategic-giving connects charitable behavior to sales-related idea and performance purpose, such as sales or product promotion, consumers appear to consider such a firm egoistic and less favor it.

\subsection{Theoretical Contributions}

Swanson (1995) propose three principal motivations: Economic, positive duty, and negative duty, for companies to engage in CSR to bridge management and business ethics research. Economic motives focus on management and performance aspects, such as sales, profit, and return on investment, while the duty-aligned perspectives usually adopt ethical perspectives focusing on corporate moral behaviors and the associated obligations to society. Positive duty concerns a firm's involvement in CSR to help others, while negative duty refers to that a company's motivation in CSR may be an exercise in limit to meet stakeholder expectations. The current values- and strategic-driven findings appear consistent with Swanson's CSR motive attribution (1995) in the aspect of positive and negative duty. Whereas different from Swanson's mutual, economic theory, the stakeholder-driven motive reveals a negative aspect of duty in the current study.

Our findings also support Porter and Kramer's perspective for charity. Porter and Kramer (2002) assert that true strategic charity states simultaneously the social and economic goals, affecting areas where the firm and society both benefit; thus, strategic pragmatisms are simply for publicity, has nothing to do with strategy or promoting product or brand. Indeed, the current mediation test reveals that through evaluation of firm's commitment to CSR-giving, particularly when it is perceived altruistic, others-interested, consumers would go further to infer the company's credibility, and the connection is positive - the more altruism inferred, the higher the credibility imparted to the firm's reputation and purchase intention. However, this positivity can be much reduced when the firm lets consumers perceive the giving is hidden with self-interest purpose.

\subsection{Limitations}

We conclude this study by explaining several limitations and possible directions for future research. First, although signaling theory provides us clear guidance in connecting corporate social giving to consumer attribution, the experiment is not without difficulty. The means to objectively discern the elements of values, strategy, and attitude, and whether the results thus derived are reliable, require further confirmation. For instance, we had difficulty discerning the boundary between others- and stakeholders- driven measures. Other types of corporate giving aside from the current sales- and non-sales paired giving may also require further scrutiny for experimental robustness.

Second, this study only examined the inference of consumers on claims of giving, without checking whether there were deviations in the information cues delivered. The use of a series of focus groups or in-depth interviews may allow a deeper understanding of exactly how and why the inferences are different in the same scenario. Finally, we also need to urge caution in interpreting the findings, because the current sample was limited. Uses of alternative age groups would allow a comparison to uncover specific differences in attitudes across generations regarding different 
personal characteristics, which may provide an improved validity check for the data. A longitudinal study over a period of time may be able to adjust the potential biases.

\section{Acknowledgements}

This autheor thanks the support of Ministry of Science and Technology, Taiwan, No: 102-2410-H-006 -045 -SS3.

\section{References}

Berman, J. Z., Levine, E..E., Barasch, A. \& Small, D. A. (2015). The braggart's dilemma: On the social rewards and penalties of advertising prosocial behavior. Journal of Marketing Research, 52(1), 90-104. https://doi.org/10.1509/jmr.14.0002

Berglind, M., \& Nakata, C. (2005). Cause-related marketing: More buck than bang? Business horizons, 5(48), 443-453. https://doi.org/10.1016/j.bushor.2005.04.008

Bhattacharya, C.B. \& S. Sankar (2004). Doing better at doing good: When, why, and how consumers respond to corporate social initiatives. California Management Review, 47(1), 9-24. https://doi.org/10.2307/41166284

Cantrell, J., Kyriazis, E. \& Noble, G. (2015). Developing CSR giving as a dynamic capability for salient stakeholder management. Journal of Business Ethics, 130(2), 403-421. https://doi.org/10.1007/s10551-014-2229-1

Castaldo, S., Perrini, F., Misani, N. \& Tencati, A. (2009). The missing link between corporate social responsibility and consumer trust: The case of Fair Trade products. Journal of Business Ethics, 84(1), 1-15. https://doi.org/10.1007/s10551-008-9669-4

Connelly, B.L., Certo, S.T., Ireland, R.D., \& Reutzel, C.R. (2011). Signaling theory: A review and assessment. Journal of Management, 37(1), 39-67. https://doi.org/10.1177/0149206310388419

Dodds, W., Monroe, K. B. \& Grewal, D. (1991). Effects of price, brand, and store information on buyers' product evaluations, Journal of Marketing Research, 28(3), 307-319. https://doi.org/10.2307/3172866

Du, S. \& Chandran, S. (2009). When does being good imply doing good? Exploring context effects on corporate social responsibility. Advances in Consumer Research - Asia-Pacific Conference Proceedings. 8, 67-67.

Elfenbein, D.W., Fisman, R. \& Mcmanus, B. (2012). Charity as a substitute for reputation: Evidence from an online marketplace. Review of Economic Studies, 79(4), 1441-1468. https://doi.org/10.1093/restud/rds012

Ellen, P. S., Webb, D. J., \& Mohr, L. A. (2006). Building corporate associations: Consumer attributions for corporate socially responsible programs. Journal of the Academy of Marketing Science, 34(2), 147-157. https://doi.org/10.1177/0092070305284976

Friedman, M.(1970). A Friedman Doctrine: The social responsibility of business of business is to increase profit. The New York Times Magazine, September, 13, 32-33.

Gan, A. (2006). The impact of public scrutiny on corporate philanthropy. Journal of Business Ethics, 69, 217-236. https://doi.org/10.1007/s10551-006-9087-4

Groza, M. D., Pronschinske, M. R., \& Walker, M. (2011). Perceived organizational motives and consumer responses to proactive and reactive CSR. Journal of Business Ethics, 102(4), 639-652. https://doi.org/10.1007/s10551-011-0834-9

Henderson, M. T. \& Malani, A. (2009). Corporate philanthropy and the market for altruism. Columbia Law Review, 109(3), 571-627.

Levin, I. P., Schneider, S. L., \& Gaeth, G. J. (1998). All Frames are not created equal: A typology and critical analysis of framing effects. Organizational Behavior and Human Decision Processes, 76(2), 149-188. https://doi.org/10.1006/obhd.1998.2804

Mavlanova, T. Benbunan-Fich, R., \& Koufaris, M. (2012). Signaling theory and information asymmetry in online commerce. Information \& Management, 49, 240-247. https://doi.org/10.1016/j.im.2012.05.004

Nan, X., \& Heo, K. (2007). Consumer responses to corporate social responsibility (CSR) initiatives: Examining the role of brand-cause fit in cause-related marketing. Journal of Advertising, 36(2), 63-74. https://doi.org/10.2753/JOA0091-3367360204

Newburry, W. (2010). Reputation and supportive behavior: Moderating impacts of foreignness, industry and local exposure. Corporate Reputation Review, 12(4), 388-405. https://doi.org/10.1057/crr.2009.27

Peloza, J., Hudson, S. \& Hassay, D. (2009). The marketing of employee volunteerism. Journal of Business Ethics, 85, 
371-386. https://doi.org/10.1007/s10551-008-9734-Z

Pivato, S., Misani, N. \& Tencati, A. (2008). The impact of corporate social responsibility on consumer trust: the case of organic food. Business Ethics: A European Review, 17(1), p3-12. https://doi.org/10.1111/j.1467-8608.2008.00515.x

Porter M.E. \& Kramer M.R. (2002). The competitive advantage of corporate philanthropy, Harvard Business Review, December.

Ricks, Jr. J. M. \& Williams, J. A. (2005). Strategic corporate philanthropy: Addressing frontline talent needs through an educational giving program. Journal of Business Ethics, 60(2), 147-157. https://doi.org/10.1007/s10551-005-1175-3

Saiia, D. H., Carroll, A. B. \& Buchholtz, A. K. (2003). Philanthropy as strategy: When corporate charity begins at home. Business and Society, 42, 169-201. https://doi.org/10.1177/0007650303042002002

Sen, S., \& Bhattacharya, C. B. (2001). Does doing good always lead to doing better? Consumer reactions to corporate social responsibility, Journal of marketing Research, 38(2), 225-243. https://doi.org/10.1509/jmkr.38.2.225.18838

Spence, M. (2002). Signaling in retrospect and the informational structure of markets. American Economic Review, 92(3), 434-459. https://doi.org/10.1257/00028280260136200

Swanson, D. L. (1995). Addressing a theoretical problems by reorienting the corporate social performance model. Academy of Management Review, 20(1), 43-64.

Varadarajan, P.R., \& Menon, A. (1988). Cause-related marketing: A co-alignment of marketing strategy and corporate philanthropy. Journal of Marketing, 52, 58-74. https://doi.org/10.2307/1251450

Webb, D. J., \& Mohr, L. A. (1998). A typology of consumer responses to cause-related marketing: From skeptics to socially concerned. Journal of Public Policy \& Marketing, 17(2), 226-238.

Weiner, B. (1985). An attributional theory of achievement motivation and emotion. Psychological Review, 92, 538-573. https://doi.org/10.1037/0033-295X.92.4.548

Weiner, B. (2000). Attributional Thoughts about Consumer Behavior. Journal of Consumer Research, $27(3), 382-387$. https://doi.org/10.1086/317592 